\title{
PENERAPAN ASSERTIVE BEHAVIOR THERAPY UNTUK MENURUNKAN PERILAKU AGRESI PADA REMAJA DI LEMBAGA $X$
}

\author{
Yosephine Mulyahardja ${ }^{1}$, Titi P. Natalia ${ }^{2}$ \\ ${ }^{1}$ Program Studi Magister, Fakultas Psikologi, Universitas Tarumanagara Jakarta \\ Email:yvneika@gmail.com \\ ${ }^{2}$ Fakultas Psikologi, Universitas Tarumanagara Jakarta \\ Email: titinatalia.2015@gmail.com
}

\begin{abstract}
ABSTRAK
Masa remaja merupakan masa transisi dari masa anak-anak ke masa dewasa di mana terjadi perubahan biologis, kognitif dan sosioemosional yang berupa perubahan psikososial atau kematangan mental yang akan membentuk sikap, nilai dan minat baru untuk mempersiapkan diri memasuki usia dewasa. Masa remaja juga ditandai dengan sifat negatif misalnya berkaitan dengan sikap sosial berupa menarik diri dari masyarakat dan agresif terhadap masyarakat. Hal tersebut ditandai dengan meningkatnya tindak kekerasan yang terjadi yang dilakukan oleh remaja. Ketidakmampuan remaja dalam mengantisipasi konflik akan menyebabkan perasaan gagal yang mengarah pada frustrasi. Bentuk reaksi yang terjadi akibat frustrasi yakni perilaku kekerasan untuk menyakiti diri atau orang lain, yang disebut agresi.Perilaku agresi ini dapat diintervensi dengan assertive behavior therapy (ABT). ABT akan mengajarkan kepada remaja mengenai cara menyampaikan pikiran dan emosi negatif secara lebih tepat. Kelima partisipan merupakan remaja laki-laki dan anak didik pemasyarakatan di Lembaga X. Selain itu, kelima partisipan memiliki riwayat tawuran dan kesulitan untuk mengontrol emosi saat dihadapkan dengan situasi yang tidak menyenangkan. Penelitian ini menggunakan quantitative one group pre-test post-test design. Alat ukur yang digunakan adalah Buss-Perry Aggression Question, untuk mengetahui perbandingan hasil sebelum dan sesuadah pemberian intervensi. ABT yang akan dijalankan berjumlah 7 sesi, yang berlangsung selama -/+ 90 menit pada masing-masing sesi. Total skor dari keseluruhan partisipan tidak banyak menunjukkan penurunan agresi. Hasil penelitian menunjukkan bahwa ABT kurang efektif menurunkan perilaku agresi dari partisipan di Lembaga X. Hal ini bisa dikarenakan faktor inteligensi partisipan dan lingkungan sekitar partisipan.
\end{abstract}

Kata Kunci: agresi, remaja, assertive behavior therapy, ABT

\section{ABSTRACT}

Adolescence is a period of transition from childhood to adulthood where biological, cognitive and socioemotional changes occur in the form of psychosocial changes or mental maturity that will form new attitudes, values and interests to prepare for entering adulthood. Adolescence is also characterized by negative traits, for example, in relation to social attitudes in the form of withdrawing from society and being aggressive towards society. This is indicated by the increase in violence committed by adolescents. The inability of adolescents to anticipate conflicts will cause feelings of failure that lead to frustration. Forms of reaction that occur due to frustration include violent behavior to hurt themselves or others is called aggression. Aggressive behavior can be intervened with assertive behavior therapy (ABT). ABT will teach adolescents how to convey negative thoughts and emotions more precisely. The participants were five teenage boys who were correctional students at Institution $X$. In addition, the five participants had a history of brawls and difficulty in controlling emotions when confronted with unpleasant situations. This study uses quantitative one group pre-test post-test design. The measuring instrument used was the Buss-Perry Aggression Question, to find out the comparison of results before and after intervention. ABT was administered across 7 sessions, which lasted for - / +90 minutes for each session. The total score of all participants did not show significant decrease in aggression. The results showed that $A B T$ was less effective in reducing aggressive behavior of participants in Institution X. This could be due to the intelligence level of participants and the environment around the participants.

Keywords: aggression, adolescents, assertive behavior therapy, $A B T$

\section{PENDAHULUAN}

\section{Latar Belakang}

Remaja adalah generasi yang paling berpengaruh dalam mewujudkan cita-cita suatu bangsa dan generasi penerus yang diharapkan bisa merubah keadaan bangsanya menjadi bangsa yang lebih 
baik. Santrock (2007) mendefinisikan remaja sebagai masa perkembangan transisi antara anak dan masa dewasa yang mencakup perubahan biologis, kognitif, dan sosialemosional. Santrock (2007) juga menambahkan bahwa perubahan kognitif meliputi perubahan dalam pikiran, kecerdasan dan perilaku, sedangkan perubahan sosialemosional meliputi perubahan dalam hubungan individu dengan manusia lain, baik keluarga maupun lingkungan sekitar, dalam emosi, kepribadian dan konsep diri. Berdasarkan defenisi di atas, disimpulkan bahwa remaja merupakan masa transisi dari masa anak-anak ke masa dewasa di mana terjadi perubahan biologis, kognitif dan sosioemosional yang berupa perubahan psikososial atau kematangan mental yang akan membentuk sikap, nilai dan minat baru untuk mempersiapkan diri memasuki usia dewasa.

Menurut Monks (1999) masa remaja juga ditandai dengan sifat negatif misalnya berkaitan dengan sikap sosial berupa menarik diri dari masyarakat dan agresif terhadap masyarakat. Hal tersebut ditandai dengan meningkatnya tindak kekerasan yang dilakukan oleh remaja. Menurut Santrock (2007) remaja belum mampu untuk menguasai fungsi-fungsi fisik maupun psikisnya. Kekurangan kemampuan dalam menguasai fungsi fisik dapat membawa dampak psikologis terutama berkaitan dengan adanya gejolak emosi dan tekanan jiwa sehingga mudah menyimpang dari aturan dan norma sosial yang berlaku.

Menurut Havighurst (dalam Hurlock, 2006), Perkembangan emosi pada remaja ditandai dengan emosi yang tidak stabil dan penuh gejolak, sehingga mood bisa berubah dengan sangat cepat. Namun, remaja bertugas mencapai kemandirian emosional dari orangtua dan orang-orang dewasa lainnya yang bisa membuat remaja melawan keinginan atau bertentangan pendapat dengan orang tuanya (Hurlock, 2006). Ketidakmampuan remaja dalam mengantisipasi konflik akan menyebabkan perasaan gagal yang mengarah pada frustrasi. Bentuk reaksi yang terjadi akibat frustrasi yakni perilaku kekerasan untuk menyakiti diri atau orang lain, yang disebut agresi.

Perilaku agresi secara psikologis cenderung menyerang sesuatu yang dipandang sebagai hal yang mengecewakan, menghalangi atau menghambat. Perilaku ini terjadi pada masa perkembangan, karena pada masa inilah seorang anak sudah mulai merasa ingin mengetahui dan ingin melakukan sesuatu yang dia inginkan walaupun tanpa dia sadari sesuatu yang dia lakukan itu dapat berdampak negatif pada dirinya sendiri ataupun pada orang lain (Hurlock, 2006).

Menurut Murray (dalam Hall \& Lindzey, 2005), agresi dapat didefinisikan sebagai suatu cara untuk melawan dengan sangat kuat, berkelahi, melukai, menyerang, membunuh, atau menghukum orang lain. Secara singkatnya. agresi adalah tindakan yang dimaksudkan untuk melukai orang lain. Agresi merupakan perilaku yang dimaksudkan untuk menyakiti orang lain baik fisik maupun psikologis. Apabila terjadi perilaku menyakiti orang lain, adanya suatu tindakan medis secara fisik menyakiti, yang dilakukan tanpa unsur kesengajaan bukan termasuk tindakan agresif. Tetapi jika terdapat niatan dengan sengaja menyakiti orang lain, walaupun tidak berhasil, tergolong sebagai suatu tindakan agresif.

Atkinson (2008), menyatakan bahwa agresi merupakan suatu reaksi emosional. Havighrust (dalam Hurlock, 2006), menyatakan bahwa tugas perkembangan remaja adalah mencapai kemandirian emosi. Maka dapat ditarik kesimpulan bahwa kecenderungan agresivitas pada remaja awal adalah perilaku menyakiti orang lain yang dilakukan remaja yang tidak dapat mencapai kemandirian emosi yang baik, secara fisik maupun verbal terhadap individu atau objek lain dan dilakukan semata-mata sebagai pelampiasan keinginan untuk menyakiti dan melukai individu dan objek lain. 
Perilaku agresi salah satunya dapat diintervensi dengan assertive behavior therapy (ABT) (Zare dan Faharani dalam Stevani, Basaria, dan Irena, 2018). Dalam hal ini, assertive behavior therapy, yang biasa dikenal juga dengan assertiveness training, assertion training, atau social skills training, merupakan prosedur melatih seseorang dalam hal berperilaku sosial yang tepat untuk mengekspresikan perasaan, tindakan, opini, dan haknya, yang berakar pada terapi perilaku (DeVito, 2013). ABT mengajarkan individu untuk berperilaku dengan menyertakan beberapa faktor dalam meningkatkan kompetensi sosial yaitu dari faktor kognitif, emosi, dan perilaku (Lorr \& More,1980).

Dalam latihan ini anak dilatih dalam bersikap asertif untuk menghadapi berbagai situasi dan diharapkan adanya perubahan perilaku yang lebih positif melalui proses belajar pada remaja dari sebelum dengan sesudah latihan dan dapat menurunkan perilaku agresif ke perilaku asertif pada diri remaja (Sunardi, 2010). Cara yang digunakan dalam latihan ini adalah dengan permainan peran dalam diskusi kelompok. Duckworth dan Mercer (2006) mengatakan bahwa latihan asertif adalah metode yang efektif diterapkan pada anak yang berperilaku agresif, karena latihan asertif lebih menekankan pada modeling dan role play.

\section{Rumusan Masalah}

Permasalahan pada penelitian ini adalah apakah penerapan assertive behavior therapy dapat menurunkan perilaku agresi pada remaja di Lembaga X?

\section{METODE PENELITIAN}

\section{Partisipan}

Partisipan dalam intervensi kelompok ini adalah lima remaja laki-laki yang berusia kisaran 16-18 tahun dan merupakan anak didik pemasyarakatan (andikpas) di Lembaga X. Kelima partisipan ini bergabung ke Lembaga $X$ karena kasus penganiayaan, pencurian, dan asusila. Selain itu, kelima partisipan juga memiliki riwayat tawuran dan kesulitan mengontrol emosi ketika dihadapkan pada situasi yang tidak menyenangkan.

\section{Desain Penelitian}

Desain penelitian yang digunakan adalah quantitative one group pre-test post-test design, yaitu metode kuantitatif dengan menggunakan pre-test dan post-test yang berguna untuk melihat apakah ada penurunan pada aspek agresi sebelum dan sesudah intervensi diberikan.

\section{Setting Lokasi}

Penelitian ini dilakukan di ruang perpustakaan yang ada di Lembaga X, yang memiliki visi untuk menjadi institusi terpercaya dalam memberikan pelayanan, perlindungan, pembimbingan, pembinaan, dan pendidikan anak didik pemasyarakatan.

\section{Pengukuran}

Skala perilaku agresif yang digunakan adalah Buss-Perry Aggression Question, instrumen yang dikembangkan oleh Bryant dan Smith (2001). AQ-SF ini terdiri dari 12 item untuk mengukur 4 dimensi dari agresi, yaitu agresi fisik, agresi verbal, kemarahan, dan permusuhan. AQ-SF menggunakan skala 1-6, dengan 1 utuk 'sangat tidak menggambarkan saya' dan 6 untuk 'sangat menggambarkan diri saya'.

Selain itu, tes grafis juga dilakukan untuk mengetahui gambaran kepribadian partisipan dan mengetahui konsep diri yang dimiliki. Tes grafis juga dapat digunakan untuk melihat indikasi agresi pada partisipan. Analisa gambar dilakukan berdasarkan beberapa prinsip interpretasi Ogdon (1974). 


\section{HASIL DAN PEMBAHASAN}

\section{Gambaran partisipan}

Secara umum, kelima partisipan ini berusia adolescence atau remaja yang berada pada rentang usia 16-18 tahun dan telah menjadi anak didik pemasyarakatan. Dalam tes grafis, anak cenderung menggambar bentuk yang tajam dan tekanan garisnya kuat. Selain itu, anak juga memiliki riwayat tawuran dan cenderung kesulitan mengontrol emosi yang dimiliki ketika dihadapkan pada situasi tidak menyenangkan.

\section{Pelaksanaan Intervensi}

Sebelum melakukan intervensi, penulis terlebih dahulu melakukan screening berupa autoanamnesa, tes inteligensi dengan menggunakan CFIT skala 3A dan tes grafis (DAM, BAUM, dan Wartegg) untuk mengetahui tingkat agresivitas, bentuk agresivitas dan gejala agresivitas yang ditampilkan partisipan. Demikian pula setelah intervensi selesai dilakukan diberikan post-test untuk kelima partisipan, pemberian kuesioner dan tes grafis (DAM dan BAUM) untuk mengevaluasi adanya penurunan agresivitas yang dialami oleh masing-masing partisipan. Intervensi yang akan dijalankan berjumlah 7 sesi, di mana masing-masing sesi berlangsung selama -/+ 90 menit. Adapun rincian kegiatan dengan rancangan jadwal kegiatan sebagai berikut:

Tabel 1.

Prosedur Intervensi

\begin{tabular}{|c|c|c|c|c|}
\hline Sesi & Tujuan & Rincian kegiatan & $\begin{array}{l}\text { Total } \\
\text { Durasi }\end{array}$ & Metode \\
\hline 1 & 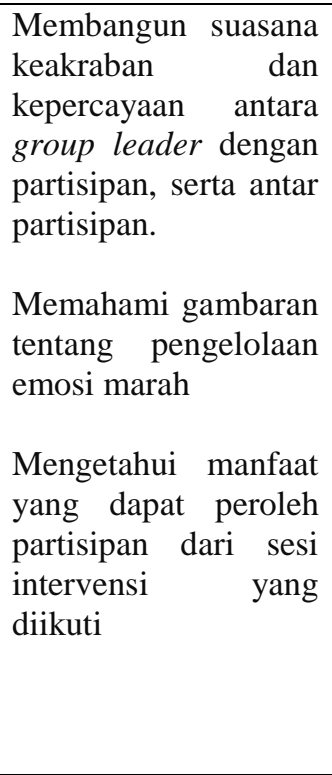 & $\begin{array}{l}\text { Pembukaan } \\
\text { Perkenalan Partisipan [10', } \\
\text { Ice Breaking [10"'] } \\
\text { Penjelasan aktivitas [10',] } \\
\text { Harapan, Kekhawatiran, } \\
\text { Kesepakatan Bersama [15'] } \\
\text { Pretest [10'] } \\
\text { Aktivitas 1 [20"] } \\
\text { Group leader menjelaskan tentang } \\
\text { agresivitas, pengelolaan emosi, dan } \\
\text { dampak pengelolaan emosi yang rendah } \\
\text { dengan bantuan Video. } \\
\text { Penutup [10'] }\end{array}$ & $85^{\prime \prime}$ & $\begin{array}{l}\text { Paper and } \\
\text { pencil } \\
\text { Diskusi } \\
\text { Video } \\
\\
\text { One to many }\end{array}$ \\
\hline 2 & $\begin{array}{l}\text { Menggali bentuk } \\
\text { perilaku partisipan } \\
\text { yang } \\
\text { mengindikasikan } \\
\text { ketidakmampuan } \\
\text { dalam mengelola } \\
\text { emosi marah. } \\
\text { Menghilangkan hal } \\
\text { negatif dalam diri }\end{array}$ & $\begin{array}{l}\frac{\text { Pembukaan }}{\text { Ice Breaking [10',] }} \\
\text { Review [15',] } \\
\text { Aktivitas } 1 \text { [20',] } \\
\text { - Group leader meminta partisipan untuk } \\
\text { menuliskan pengalaman tidak } \\
\text { menyenangkan yang sering dialami dan } \\
\text { bagaimana respon mereka. } \\
\text { - Partisipan juga diminta untuk } \\
\text { menuliskankan apa yang dilakukan pada }\end{array}$ & $85^{\prime \prime}$ & $\begin{array}{l}\text { Games } \\
\text { Diskusi } \\
\text { Paper and } \\
\text { pencil }\end{array}$ \\
\hline
\end{tabular}




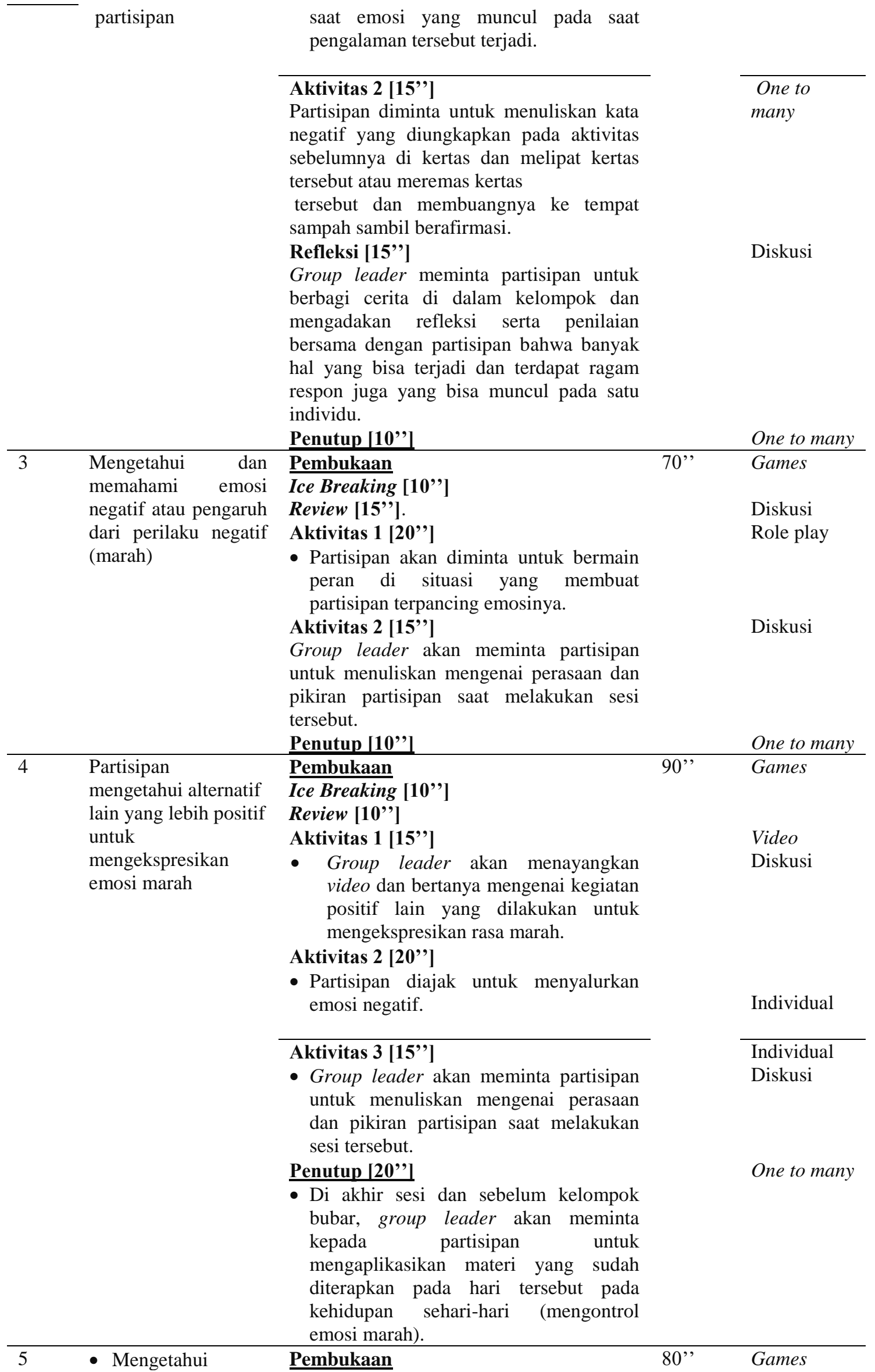




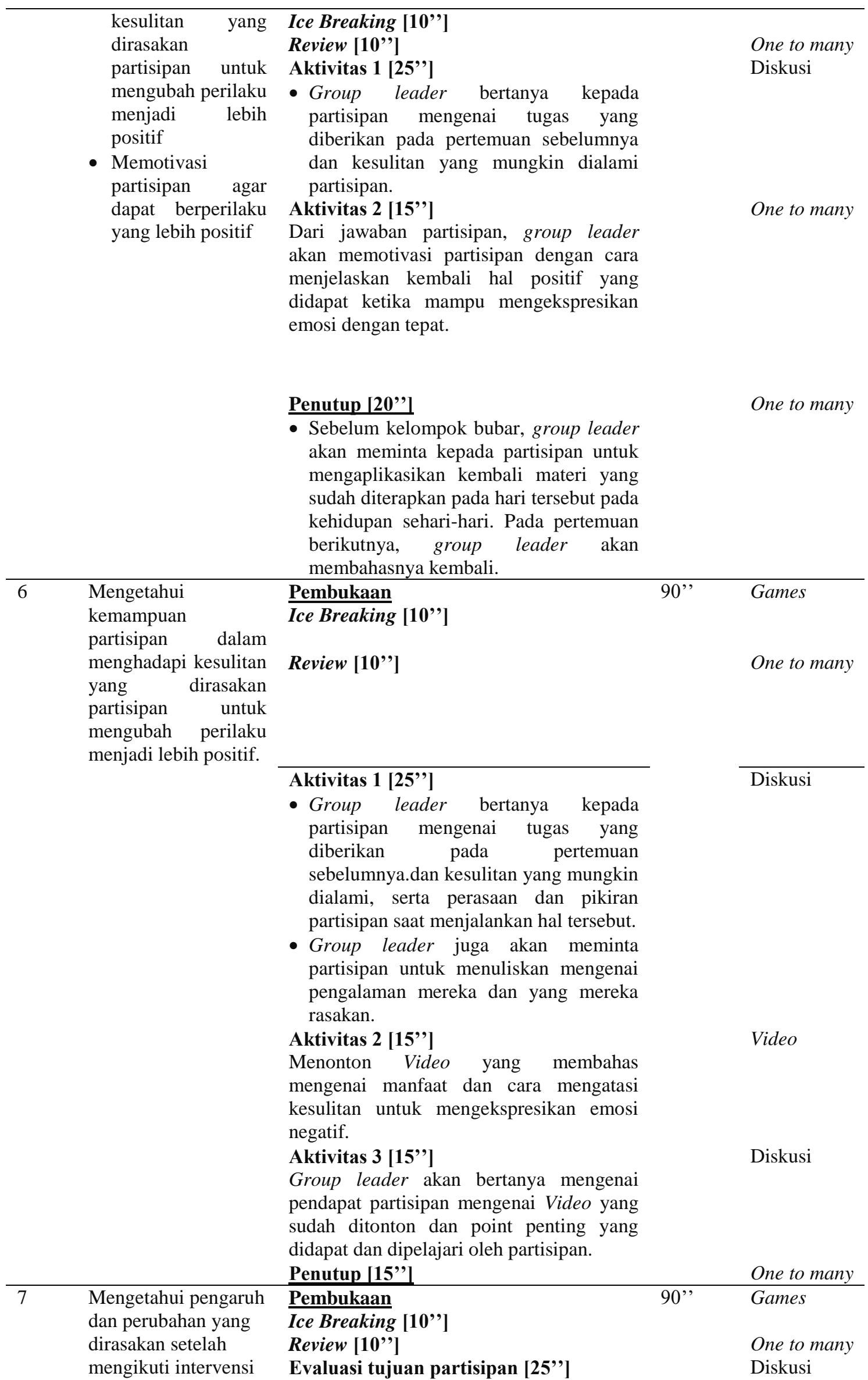




$\begin{array}{ll}\text { Review }[20,] & \begin{array}{l}\text { Individual } \\ \text { One to many }\end{array} \\ \text { Post-test }[10, '] & \text { Individual } \\ \text { Penutup }[15,] & \text { One to many }\end{array}$

\section{Hasil Intervensi}

Intervensi kelompok yang dilakukan dengan menggunakan metode assertive behavior therapy (ABT) tidak dapat menurunkan perilaku agresi pada partisipan yang mengikuti tujuh sesi group assertive behavior thereapy. Hal ini ditandai dengan tidak adanya perubahan pada skala pengukuran agresivitas. Pada skala pengukuran agresivitas pada seluruh partisipan hanya menunjukkan penurunan 1-2 poin. Bahkan pada salah satu partisipan terjadi peningkatan sebanyak 10 poin dari hasil pre-test. Hal ini juga didukung dengan hasil tes grafis partisipan. Grafis pada partisipan masih cenderung menunjukkan bentuk yang tajam dan tekanan garis yang kuat. Hanya ada satu partisipan yang menunjukkan adanya perubahan gambar, seperti gambar orang yang dibuat secara utuh. Sedangkan partisipan lainnya belum menunjukkan adanya perubahan pada grafis dan skala pengukuran agresivitas.

Hasil penelitian yang dilakukan menunjukkan hasil yang berbeda dari beberapa penelitian yang dilakukan sebelumnya. Stevani, Basaria, \& Irena (2018) menunjukkan bahwa ABT dapat berhasil menurunkan perilaku agresivitas verbal pada anak middle childhood. Penelitian dari Zare dan Faharani (dalam Stevani, Basaria, \& Irena, 2018) mengenai ABT yang dilakukan dengan metode training dapat membantu para suster dalam mengatur kemarahan mereka saat mereka sedang bekerja di rumah sakit. Namun, yang perlu menjadi pertimbangan pertama adalah, ABT melibatkan proses kognitif. Menurut, Lorr \& More (1980) terdapat tiga aspek penting dalam ABT, salah satunya adalah rekonstruksi kognitif. Sedangkan pada kelima partisipan, hasil inteligensi cenderung rendah. Hal inilah yang bisa menjadi salah satu penyebab tidak berhasilnya penerapan intervensi pada penelitian peneliti.

\section{KESIMPULAN DAN SARAN}

Penerapan metode assertive behavior therapy pada remaja di Lembaga $X$ tidak dapat menurunkan perilaku agresi. Hal ini ditandai dengan tidak adanya perubahan yang nampak pada skala pengukuran agresivitas dan tes grafis. Tidak berhasilnya penerapan metode assertiveness behavior therapy pada remaja di Lembaga $\mathrm{X}$ bisa dikarenakan faktor inteligensi pada partisipan. Kelima partisipan memiliki inteligensi berkisar 57-75, yang berarti berada di bawah rata-rata. Sedangkan bentuk intervensi yang diberikan adalah assertive behavior therapy yang melibatkan proses berpikir. Sehingga partisipan agak sulit untuk menangkap dan memahami isi intervensi yang disampaikan oleh group leader. Meskipun intervensi tersebut sudah dirancang sesederhana mungkin, terdapat faktor lain yang bisa memengaruhi tidak adanya perubahan pada perilaku agresi partisipan.

Faktor lain yang dimaksud adalah faktor lingkungan yang membuat partisipan kesulitan mengubah perilaku agresi. Partisipan merupakan anak didik di Lembaga X, di mana banyak hal yang dapat menjadi penyebab partisipan tidak mampu mengontrol emosi dan berperilaku agresi. Salah satu contohnya, karena teman sekamar yang tidak menyenangkan atau diperlakukan tidak menyenangkan oleh lingkungan.

Selain itu, kondisi partisipan juga pada saat pengambilan data post-test juga dapat memengaruhi perubahan perilaku partisipan. Salah satu contoh, partisipan G yang sudah menunjukkan adanya 
perubahan selama sesi. Tetapi pada hari pengambilan data post-test, suasana hati G sedang tidak baik atau sedang ada masalah. Sehingga memengaruhi hasil grafis G yang bisa dikatakan semakin kurang baik dari sebelumnya.

Meskipun partisipan tidak menunjukkan adanya perubahan pada perilaku agresi, partisipan menunjukkan perubahan dalam mengikuti sesi intervensi. Pada beberapa sesi awal, partisipan cenderung saling mengejek dan selalu memberikan komentar ketika group leader ataupun ada partisipan lain yang sedang berbicara. Namun pada tiga sesi terakhir, perilaku partisipan tersebut sudah mulai berkurang bahkan tidak muncul sama sekali pada sesi terakhir.

\section{Saran}

Beberapa saran yang dapat dipertimbangkan untuk penelitian selanjutnya, yaitu:

1. Mempertimbangkan faktor inteligensi apabila ingin menggunakan intervensi assertive behaviour therapy.

2. Mempertimbangkan lingkungan sekitar subjek, ada kemungkinan faktor lingkungan subjek, yaitu di lapas, dapat memengaruhi ada atau tidaknya perubahan perilaku subjek.

\section{Ucapan Terima Kasih}

Penulis berterima kasih kepada partisipan yang terlibat dalam penelitian ini. Penulis juga mengucapkan terima kasih kepada pihak lembaga ' $\mathrm{X}$ ' yang sangat membantu dalam penyediaan ruangan dan membantu terlaksananya proses terapi.

\section{REFERENSI}

Atkinson, R. (2008).Pengantar Psikologi. Jakarta : Erlangga

Bryant, F. B., \& Smith, B. D. (2001). Refining the Architecture of Aggression: A Measurement Model for the Buss-Perry Aggression Questionnaire. Journal of Research in Personality. $35,138-167$.

DeVito, J.A. (2013). The Interpersonal communication book, $13^{\text {th }}$ Edition. Boston: Pearson

Hall, C.S., \& Lindzey, G. (2005). Kepribadian psikologi. Yogyakarta: Kanisius.

Hurlock, E. B. (2006). Psikologi perkembangan suatu pendekatan sepanjang rentang kehidupan. Edisi kelima. Jakarta: Erlangga.

Lioni, A., \& Pratiwi, T. I. (2013). Penerapan assertive training untuk mengurangi perilaku negatif berpacaran pada siswa kelas x-1 di sma negeri 1 porong. Jurnal Mahasiswa Teknologi Pendidikan, 4(1)45-53

Lorr, M., \& More, W. W. (1980). Four dimensions of assertiveness. Multivariate Behavioral Research, 15(2), 127-138.

Milovanovic, R., Miladinovic, I. C., \& Stojanovic, B. (2017). Assertiveness of prospective teachers and preschool teachers. Journal Plus Education, 16(2), 289-303.

Myers, D. G. (2010). Social psychology (10 ${ }^{\text {th }}$ ed.). New York, NY: McGraw-Hill.

Santrock, J. W. (2007). Perkembangan remaja jilid 2 (Edisi 11). Jakarta: Erlangga.

Stevani, Basaria, D. \& Irena, F. (2018). Penerapan assertive behavior therapy untuk menurunkan perilaku agresi verbal pada anak di Lembaga X. Jurnal Muara Ilmu Sosial, Humaniora, dan Seni, 2(1), 205-214.

Sunardi. (2010). Latihan asertif. Bandung: PLB FIP UPI, dalam http://file.upi.edu/SUNARDI/LATIHASE RTIF diperoleh 1 Maret 2014. 